
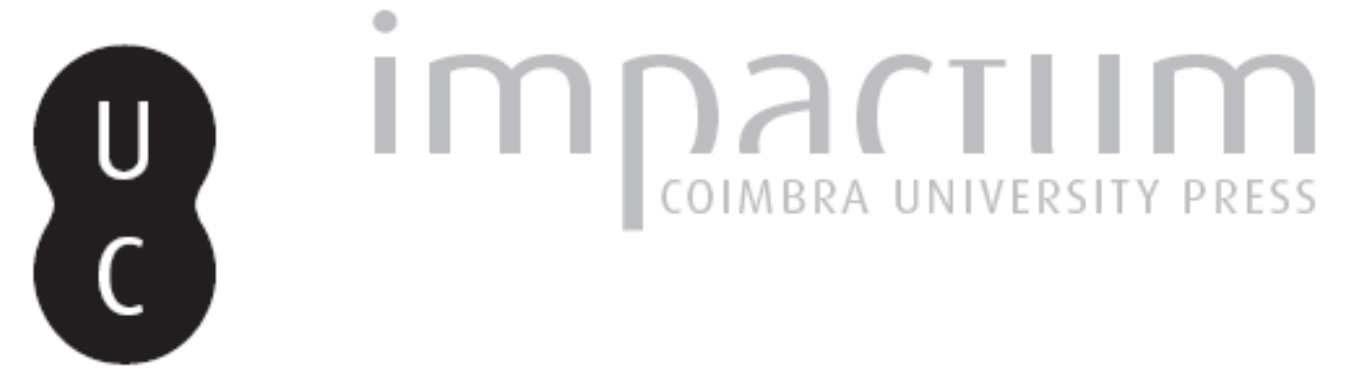

Sobre três inscrições perdidas da Bobadela: (Oliveira do Hospital)

Autor(es): $\quad$ Amaral, A. E. Maia do

Publicado por: Imprensa da Universidade de Coimbra

URL persistente:

URI:http://hdl.handle.net/10316.2/45703

DOI:

DOI:https://dx.doi.org/10.14195/1647-8657_21_2

Accessed : $\quad$ 26-Apr-2023 12:10:52

A navegação consulta e descarregamento dos títulos inseridos nas Bibliotecas Digitais UC Digitalis, UC Pombalina e UC Impactum, pressupõem a aceitação plena e sem reservas dos Termos e Condições de Uso destas Bibliotecas Digitais, disponíveis em https://digitalis.uc.pt/pt-pt/termos.

Conforme exposto nos referidos Termos e Condições de Uso, o descarregamento de títulos de acesso restrito requer uma licença válida de autorização devendo o utilizador aceder ao(s) documento(s) a partir de um endereço de IP da instituição detentora da supramencionada licença.

Ao utilizador é apenas permitido o descarregamento para uso pessoal, pelo que o emprego do(s) título(s) descarregado(s) para outro fim, designadamente comercial, carece de autorização do respetivo autor ou editor da obra.

Na medida em que todas as obras da UC Digitalis se encontram protegidas pelo Código do Direito de Autor e Direitos Conexos e demais legislação aplicável, toda a cópia, parcial ou total, deste documento, nos casos em que é legalmente admitida, deverá conter ou fazer-se acompanhar por este aviso.

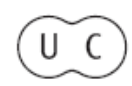


FACULDADE DE LETRAS

INSTITUTO DE ARQUEOLOGIA

\section{CONIMBRIGA}

VOLUMEXXI

UNIVERSIDADE DE COIMBRA

1982 


\author{
A. E. Maia do Amaral \\ Licenciado em História
}

\title{
SOBRE TRÊS INSCRIÇÕES PERDIDAS DA BOBADELA (OLIVEIRA DO HOSPITAL)
}

Conimbriga, XXI (1982), p. 101-126

RESUM O: O autor apresenta alguns subsídios provisórios para o estudo de três inscrições monumentais da Bobadela: do fragmento CIL 5245, publica-se fotografia; quanto à dedicatória à splendidissima civitas, conhecida por um apògrafo que se demonstra estar incompleto, propõe-se uma restituição baseada num poema seiscentista: o texto íntegro comemoraria a refecção das portas do forum por uma flaminica; de um texto funerário sob a invocação à Pietas, esclarecem-se equívocos antigos e, com base num fragmento pouco conhecido, é proposta uma nova paginação e uma datação do séc. II d.C.; sugere-se que provenha de um mausoléu.

RÉSUMÉ: Trois inscriptions de Bobadela, réputées perdues, sont étudiées sous quelques aspects de détail, quoique en profondeur. Un gros fragment votif (CIL II 5245) est publié d'après un moulage peu connu. Un autre texte monumental, dédié à la splendidissima civitas et dont ne subsiste qu'une copie partielle datée de 1746 (CIL II 397), fait l'object d'un essai de restitution basée sur un poème du dix-septième siècle: il commémorerait la réfection des portes du forum. Pour une inscription qui invoque la Pietas (CIL II 396), et qui pourrait provenir d'un mausolée, l'auteur, en ayant repéré un fragment au Musée de Coimbra, propose une nouvelle mise en page et une datation paléographique du Ilème siècle ap.J.C. 
(Página deixada propositadamente em branco) 


\title{
SOBRE TRÊS INSCRIÇÕES PERDIDAS DA BODADELA
}

\author{
(OLIVEIRA DO HOSPITAL) *
}

Elaborando o «Inventário Arqueológico» do concelho de Oliveira do Hospital, tivemos ocasião de nos demorar no estudo de algumas inscrições latinas, provenientes da Bobadela, sede da freguesia daquele concelho beirão.

Ninguém ignora a importância da ciência epigráfica para os estudos históricos, nomeadamente no que à época romana diz respeito: tanto pela abundância de documentos, como pela variedade das informações que veiculam, como por corresponder, geralmente, o seu achado ao local de fabrico/utilização, como ainda, por se tratar de documentos originais.

Mais, no caso presente, as fontes epigráficas são, de facto, no conjunto, os melhores materiais de que actualmente se dispõe, para o estudo daquela povoação, razões por que não podiam deixar de nos merecer no «Inventário», um lugar de relevo... Não se prevendo, entretanto, a próxima publicação deste trabalho, que decorre ainda, pareceu-nos útil enunciar algumas conclusões provisórias que soubessem suscitar novas reflexões.

Escolhemos, para isso, três inscrições, todas perdidas: o monumental fragmento, provavelmente dedicado à Vitória Eterna

* Agradecemos ao Dr. José d'Encarnaçao ter acedido a rever e comentar connosco este artigo; às suas pertinentes sugestões muito deve a presente redacção.

Conimbriga, 21 (1982), 101-126 
(CIL II 5245) e verosimilmente picado por volta de 1974, a dedicatória à «Splendidissima civitas» (CIL II 397) desaparecida após 1746 e uma suposta ara à deusa Piedade (CIL II 396), que acompanhou na sorte o paço episcopal de Coja, demolido em finais de Oitocentos.

Desde o século xvm que se conhecem abundantes referências a estas epígrafes, mas todas mais ou menos episódicas. Esforços de síntese, com efeito, nunca tentaram os estudiosos até que, em 1980, a Dr. ${ }^{a}$ Regina Anacleto redigiu a sua «Bobadela Epigráfica» 0). É este verdadeiramente «um primeiro Corpus actualizado das inscrições da Bobadela» (2), e em relação ao qual as omissões inevitáveis a que ser o primeiro dá direito, não retiram a qualidade de obra de referência utilíssima, já para não dizer obrigatória, a quem queira lograr uma panorâmica da epigrafia local. Aproveite-se para deixar claro que este artigo não visa rever ou, muito menos, substituir-se àquele: limitar-nos-emos a apresentar alguma coisa que de novo fomos encontrando sobre as três inscrições, sem a preocupação de suprir omissões ou rever conclusões. Isto porque tal contributo inédito é quanto basta à demonstração de uma vitalidade que julgamos estar longe de esgotada: o dossier actual pode ainda ser consideravelmente alterado e aumentado, com o que, sem dúvida, virá a sobressair a importância do local e a urgência de um exercício de reinterpretação.

INSCRIÇÃO N. ${ }^{\circ} 1($ CIL II $5245=$ Bob. Ep. 4)

Depois de indicar a localização da peça, no andar térreo do solar dito dos Freires de Andrade, onde era uma antiga cozinha

I') Regina Anacleto, Bobadela Epigráfica, Coimbra, 1981 (= Bob. Ep.). Publicado anteriormente (com algumas gralhas importantes) no jornal «A Comarca de Arganil», Arganil, LXXX (8055) 22 Mai. 1980, p. 1, 5; LXXX (8056) 24 Mai. 1980, p. 1, 2; LXXX (8076) $15 \mathrm{Jul}$ 1980, p. 1,5; LXXX (8082) 29 Jul. 1980, p. 1, 5; LXXX (8087) 9 Ago. 1980, p. 1,2; LXXX (8091) 21 Ago. 1980, p. 1, 5; LXXX (8117) 23 Out. 1980, p. 1,7; LXXX (8122) 4 Nov. 1980, p. 1, 5; LXXX (8129) 20 Nov. 1980, p. 1,2.

(2) Bob. Ep., p. 8. 
e hoje se encontra instalado um mini-mercado e café, a autora de «Bobadela Epigráfica», diz que as paredes foram picadas e rebocadas: «A lápide (!) lá ficou e lá se sumiu debaixo da argamassa» ${ }^{3}$ ). E vê-se obrigada a concluir que «pouco mais do que nada há a dizer (...) pelas razões óbvias da eventual destruição e inexistência de qualquer reprodução fotográfica ou decalque»!4). A propósito destas considerações, nomeadamente sobre o desaparecimento do fragmento, de que só se conhecem desenhos de rigor discutível, uma boa notícia seria já a remota hipótese de ele não ter sido picado; mas o que principalmente pretendemos dar a conhecer é o primeiro documento fotográfico da inscrição perdida (Fig. 1). Foi obtido a partir de um decalque que se exibe n.o Museu Didáctico do Instituto de Arqueologia da Faculdade de Letras de Coimbra e que, apesar da menção de «fragmento não-localizado», cremos ter razões ponderosas para considerar, desde já, identificado. Não só existem, aí, quase todas as inscrições conhecidas da Bobadela, como é flagrante a semelhança entre a nossa foto e os desenhos que a pretendem representar (Fig. 2); o Prof. Dr. Castro Nunes, que dela viu o original, também a reconheceu.

Não deixa de ser curioso analisar, agora, perante a ansiada fotografia, essas várias versões: é, por um lado, o desenho de Francisco Martins Sarmento (5), excessivamente regular, como justamente se suspeitava; é, por outro, o de E. Hübner ( $\left.{ }^{6}\right)$ que nos faz acreditar que tenha visto a inscrição, ou obtido dela outra informação que não Sarmento, que cita - e como explicar de outro modo que soubesse que ela se encontrava na cozinha duma casa próxima da igreja $\left({ }^{7}\right)$, quando o autor citado nada diz para além de que estava na Bobadela? É, finalmente, a «reconstituição provável» de R. Anacleto, sobre um apontamento de memória

(3) Bob. Ep., p. 48.

(4) Bob. Ep., p. 51.

(5) Francisco Martins Sarmento, Expedição Scientifica à Serra da Estrella em 1881, Seç̧ão de Archeologia: Relatório, Lisboa, 1883, est. Ill, fig. 6 .

( ${ }^{6}$ Aemilius Hübner, Corpus Inscriptionum Latinarum 11, Supplementum (-CIL II), Berlim, 1892, 5245.

$\left({ }^{7}\right)$ «Extat in culina domus prope ecclesiam sitae». 
feito à distância de 25 anos pelo Prof. Dr. Joáo de Castro Nunes, e que bem evidencia as armadilhas em que tal faculdade amiúde nos induz...

Quanto aos comentários epigràfico e histórico feitos pela Dr. ${ }^{a}$ Regina, o aparecimento do decalque nada altera, antes confirma, no geral, as suas asserções. De novo, podemos dar as dimensões: altura $61 \mathrm{~cm}$, largura (máxima) $32,4 \mathrm{~cm}$; as letras, irregulares, têm entre $12,5 \mathrm{~cm}$ (e) e $16,2 \mathrm{~cm}$ (i), enquanto os espaços têm: o primeiro 4,2-6,5 cm, o segundo $15,7-16,2 \mathrm{~cm}$ e o terceiro 15,5-15,8 cm. Na leitura, o $a \mathrm{em}$ nexo, no início da segunda linha, deve ser subpontado, já que a pedra está fracturada tanto à direita como à esquerda, onde atinge o $v$ e o $a \mid$ este faz nexo com o $e$, que tem a haste vertical, como se encontrava no desenho de Sarmento: as hastes horizontais desta letra não parecem perfeitamente idênticas, antes a do meio aparenta ser mais curta. Não subsistem linhas auxiliares para a paginação, nem parece que, tendo existido, hajam sido respeitadas: ver, por exemplo, as três letras da linha 1 , muito desiguais. Do que pode ler-se não repugna reconstituir:

\section{VIC[TORIAE $] / \overline{\mathrm{AET}}[\mathrm{ERN} \overline{\mathrm{AE}}]$}

A pedra foi intencionalmente partida para servir na alvenaria de uma construção, o que leva mais facilmente a pensar num pedestal ou grande bloco (do tipo dos que ornamentavam os fora), do que, por exemplo, numa placa... Quanto à tipologia, nada mais se pode, por ora, conjecturar.

Quanto à cronologia, a rudeza do trabalho interdita qualquer aproximação por métodos paleográficos.

INSCRIÇÃO N. ${ }^{\circ} 2($ CIL II $397=1$ LER $6080=$ Bob. Ep. 1)

É esta, sem dúvida, a mais citada inscrição da Bobadela $\left(^{8}\right)$. O original foi perdido após a demolição da «igreja velha», possi-

$\left.{ }^{8}\right)$ Hübner, em 1869, compilou nove fontes, principalmente manuscritas; R. Anacleto, em 1981, acrescenta como bibliografia «de interesse» mais oito obras; nós próprios já ultrapassámos a meia centena.

Coni mb riga, 21 (1982), 101-126 
velmente do século $\mathrm{xv}\left({ }^{9}\right)$, com as suas «tres naves por banda». Resta-nos um apógrafo deturpado, em granito, que constitui a sobreverga da porta da matriz actual, e onde se lê

\section{«SPLENDIDISSIME CIVITATI JV/LIA MODIS TAPLAMINIA"}

conforme mostra a figura 3 . Teria sido gravado em 1746, como o atesta o milésimo que, logo a seguir, se inscreve num rectángulo. A legenda latina encontra-se, ainda, enquadrada por uma explicação «em linguagem»:

«ESTE / LETR(eir)O / SE A=/ [texto latino] CHOV NA/ $\mathrm{JGR}(\mathrm{ej}) \mathrm{A}$ VE / LHA $\gg\left({ }^{10}\right)$.

A observação da gravura dispensa mais larga descrição, uma vez que as medidas nos parecem, para já, irrelevantes. A deturpação da última parte do texto, onde devia ler-se

\section{[I]VLIA MOD[E]STA [F]LAMINI[C]A}

(9) É o que pode conjecturar-se da existência de diversas peças de calcário do século xv na igreja; salvo se, como bem pode ter acontecido, elas vieram de outro templo, indicariam que a igreja já se encontrava então ao culto: refiram-se um S. Pedro, um Santo António em hábito de franciscano e uma «Virgem e o Menino» (Senhora da Graça) que é orago da frequesia e «obra de categoria», que já foi a Coimbra à Exposição de Cultura Medieval, por ocasião do XVI Congresso Internacional de História de Arte.

$\left({ }^{10}\right)$ «se achou» é, aqui, sinónimo de «esteve» e não de «foi achada», conforme já demonstrou a Dr. ${ }^{a}$ Regina Anacleto (Bob. Ep., nota 1, p. 16). A inscrição encontrava-se em «hüa nave», segundo o manuscrito de 1721 (Prior Miguel Alves Carrilho, Informações Paroquiais de $1721 \mathrm{n} .^{\circ} 45$. Bobadela, 1721 Maio, 31. Caderno manuscrito autógrafo do Arquivo da Universidade de Coimbra / A. U. C. sem cota, foi. 2) que consideramos mais exacto que Cardoso e seus imitadores que escreveram «nas costas da Igreja» (P. e Luís Cardoso, Diccionario Geográfico, ou noticia histórica (...) II. Lisboa, 1752, p. 192). 
foi, em grande parte, devida à pouca visibilidade de alguns traços («gastadas letras» diz uma referência antiga). Esta leitura pode confirmar-se através do recurso a outra dedicatória da mesma Júlia Modesta, que vai tratada adiante, no número três.

Depois de restituída, traduza-se «à esplendidíssima cidade a flaminica Júlia Modesta (dedicou?)».

Há um problema preliminar que, tanto quanto sabemos, nunca foi levantado e que é o da autenticidade desta epígrafe, excessiva, se não mesmo arrogante, aos olhos de quem, hoje, visita a pequena aldeia da Bobadela.

Não nos parece razoável a hipótese de um falso. $\mathrm{O}$ apògrafo que conhecemos (1746) é uma cópia sem qualquer intenção de se fazer passar por original. Não se tratando de uma invenção (conhecem-se referências anteriores), poderá ser então cópia de um apócrifo?

Ignora-se a exacta situação da lápide suposta original: se estivesse integrada como elemento construtivo no corpo original da «igreja antiga», teríamos de recuar a sua execução pelo menos ao século $\mathrm{xv}$, onde se não descortinam nem motivações nem conhecimentos para a execução de um falso tão perfeito como este, que, até hoje, não levantou suspeitas a ninguém.

Se, por outro lado, como nos parece, a inscrição foi somente recolhida na igreja, então só podemos recuar a sua factura à data da primeira referência conhecida, isto é, antes de 1656, em que faleceu o primeiro autor que - tanto quanto sabemos se the refere. Não é crível ver nele a autoria intelectual de um falso: era Brás Garcia Mascarenhas, natural de Avô, então uma próspera vila, vizinha (e rival?) da Bobadela. Grande benemérito da sua terra, onde instituiu festas, restaurou templos e até construiu uma ponte, ali viveu largos anos e aí terá escrito a maior parte da sua obra, de que, aliás, só conhecemos hoje um poema. Se tivesse sido um falsàrio, por certo encontraríamos Avô e o seu aro no centro de uma constelação de inscrições falsas, o que não acontece; por outro lado, não teria deixado de se referir à sua vila natal como grande centro romano, tanto mais que o enredo do seu «Viriato Trágico» se passa naquela 
época e nesta região; mas não: Avô é descrito na época romana como um lugar ermo, e só é introduzido no poema graças a um artifício, o sonho de Viriato:

«Aqui onde então inda a agricultura

Não compunha, como hoje, as primaveras,

Que era tudo sylvatica espessura,

Provinda de aves, povoação de feras;

Viriato Trágico, Canto XIV, oitava 105

O bravo pastor dos Herminios «de um grave sono transportado, sonha estranhezas»: é a vila de 1632-48, onde encontra o próprio poeta que lhe falará daqueles acontecimentos recentes da restauração em que tão valentemente se empenhou. Não obstante a segura existência de vestígios romanos (achados monetários, vias, eventuais resíduos de mineração) Brás Garcia resistiu com honestidade pouco vulgar a fazer da sua vila natal — nem que só no poema - uma fundação romana. Mas, independentemente da sua idoneidade, poderia ele ter sido enganado? Não nos parece, porque assim teríamos de recuar a data de execução do suposto falso, passando então a aplicarem-se os argumentos de inverosimilhança antes referidos. Além do mais, era Brás Garcia um homem culto e viajado, um excelente observador e bom conhecedor da região. Se nos descreve uma inscrição já velha, não só não temos argumentos para descrer, como temos até boas razões para o acreditar.

A segunda questão a abordar prende-se com a fixação do texto e da paginação, indispensáveis à conjectura sobre o aspecto do monumento perdido: desde E. Hübner que o texto está basicamente restituído mas mal paginado, conforme demonstrou a Dr. ${ }^{a}$ Regina Anacleto, após descobrir e utilizar com proveito, uma nova fonte manuscrita, a «Informação Paroquial de 1721»(n)

I $^{11}$ ) Prior Miguel Alves Carrilho, Informações Paroquiais de 1721 $n .^{\circ}$ 45. Bobadela, 1721 Maio 31. Caderno manuscrito autógrafo do A. U. C., sem cota. 
de que darnos facsimile na figura 4: trata-se de uma transcrição, feita a partir do pròprio original, que veio enriquecer consideravelmente o dossier, nomeadamente com um possível nexo no final, de splendidissimae e com a certeza de que a primeira linha terminava em modesta, onde há o cuidado de grafar um pequeno traço vertical: assim, a autora propôs o seguinte «arquétipo» que ela considera, não sem irredutibilidade, a sua última palavra:

\section{SPLENDIDISSIMAE CIVITATI IVLIA MODESTA FLAMINICA}

E este, portanto, o «estado da questão» (texto-paginação) no que à erudição moderna diz respeito. Mas, para nós, não é satisfatório. Imaginamo-nos a enfrentar a mesma ordem de dificuldades que levaram E. Hübner a atribuir uma lacuna a este texto (12) mas, ao contrário do sábio alemão, já não podemos pôr em causa a leitura da primeira linha, que, com base nos materiais disponíveis, se nos afigura bastante sólida. Além disso, e com base nos mesmos materiais, parece-nos «evidente» que - a estar incompleta como cremos - a inscrição continuaria após o termo flaminica: não só o autor da «Informação Paroquial» o alinha cuidadosamente pela esquerda, como um pequeno traço vertical assinala, ainda por cima, o início da linha... Resumindo, a nossa proposta resulta no seguinte:

\section{SPLENDIDISSIMAE CIVITATI IVLIA MODESTA} FLAMINICA.

Não será esta uma ordinatio tão bela nem tão clássica quanto a de Hübner, embora apresente um recorte bastante lógico: na primeira linha, a dedicatória (splendidissimae civitati), o nome e o cognome da dedicante (lidia Modesta), resultando

$$
\begin{aligned}
& \text { SPLENDI DISSIMaE - CIVITATI } \\
& \text { rVLIA - MODESTA - FLAMINIcA } \\
& \text { (...) Initio aliquid deesse indicavi ego». }
\end{aligned}
$$

Conimbriga, 21 (1982), 101-126 
daqui ganhar em importância a identificação; na segunda, menciona-se o cargo municipal (flaminica) e, certamente na parte não lida, a razão da dedicatória e, talvez, uma fòrmula de circunstância. A remota hipótese de mais linhas não deve, de igual modo, deixar de pôr-se.

É, a nosso ver, urna ordinatio tão simples, tão óbvia, que chega a ser inacreditável como, durante quase dois séculos e após 90 referências conhecidas, ela tivesse estado «bloqueada» à perspicácia de tantas dezenas de estudiosos! E foi só, finalmente, sob o peso de uma massa respeitável de documentação e de um crescendo de utensilagem teórica que «sucumbimos» perante a simplicidade tremenda de uma solução tão imediata... E não só imediata, como cientificamente muito mais fecunda, na medida em que nos deixa o enigma em aberto e fornece, por acréscimo, elementos mais seguros para a aferência das soluções possíveis.

É na procura de tais soluções que se impõe agora caminhar. À partida, duas vias se desenham: ou é o próprio original que terá que ser encontrado — como nós próprios, por momentos, julgámos ter conseguido (13) — ou será, faltando este, um documento secundário que contenha parte da sua informação utilizável, seja calco, desenho, transcrição, referência ou outro.

Conscientes de numerosas limitações, optámos pela segunda destas vias. Apesar do nosso empenhamento, não tivemos ainda a fortuna de ver significativamente ampliados os recursos documentais disponíveis, pelo que consideramos não haver evidências

(13) Servindo de banco num pátio, a escassa dezena de metros da demolida «igreja velha», encontra-se uma pedra sulcada de riscos incompreensíveis, semelhantes a escrita; o corte aparenta ser moderno (embora rude) e, no dizer dos moradores, os grafitos foram feitos por uns «pedreiros», não há muito tempo. É possível que se trate aqui de um puro mito, uma fábula com um duplo sentido de «pedreiros», mas também se pode encarar a possibilidade de um acto de certo modo mágico : gravar símbolos e riscos de acaso numa pedra que era venerável só porque «teve letras que se não podiam $1 \mathrm{er}$ ! Seja como for, a pedra tal como se encontra é insusceptível de confirmar a hipótese de identificação com o original perdido.

Conimbriga, 21 (1982), 101-126 
suficientes para as hipóteses que, apesar disso, passaremos a enunciar e que representam o nosso contributo para a reconstituição do texto.

O poeta Brás Garcia Mascarenhas tem no seu «Viriato Trágico» (1699) uns versos sempre muito citados nestas coisas e que dizem:

«Na villa hoje chamada Bobadella

Esteve antigamente uma cidade,

Que estam, de quanto fosse grande e bella,

Indiciando vestígios nesta idade.

Gastadas letras a memória d'ella,

Conservam na ruinosa antiguidade,

E cidade mui célebre a declaram

Se o tempo escureceo como a chamavam.«

Canto IV, oitava 74

Parece-nos evidente que, para dizer que «gastadas letras» se referem à Bobadela romana («grande e bella») e «cidade mui célebre a declaram», o autor conheceria a inscrição à «splendidissimas civitas», o que não pode admirar-nos já que ele conhecia bem a então vila de Bobadela: de lá era seu pai, lá tinha sua avó, tios e primos... (14). Logo, a informação importante a extrair daqui é que a inscrição já seria, então, conhecida. Desta informação, contida na oitava 74, se aperceberam António de Vasconcelos e Regina Anacleto. Mas, mais adiante, escreve o mesmo autor:

E uma principal Julia Modesta

As portas à sua custa reedifica.

Permanece um letreiro antigo d'esta

Que muito claramente o testifica

Canto IV, oitava 89

(14) Cf. António de Vasconcelos, Brás Garcia Mascarenhas: estudo de investigação histórica, Coimbra, 1922, p. 144.

Conimbriga, 21 (1982), 101-126 
Beneficiando, portanto, de sòlida cultura clàssica (15) e, verosimilmente, de menor desgaste da epígrafe, Brás Garcia Mascarenhas leu melhor que o pároco de 1721 o nome «Julia Modesta» e com certeza o cargo «flaminica», suficientemente importante para a haver considerado uma «principal» da cidade! Leu, pois, e excelentemente, tudo o que hoje sabemos que estava na lápide original: splendidissimce civitati na oitava 74 e ivlia modesta flaminica na $89 \ldots$ Mas, para além disso, refere ainda que essa personagem reedificou à sua custa umas portas que seriam, evidentemente, na cidade que quis publicamente homenagear...

Dada a natureza do texto, temos de ser severos na apreciação do valor da fonte, pois de imediato ocorre pensar-se numa «liberdade poética». Quanto à crítica externa, vimos já que Brás Garcia Mascarenhas tinha todas as possibilidades de conhecer e 1er correctamente o original da inscrição; quanto à crítica interna, depois que António Ribeiro Garcia de Vasconcelos fez,

(15) Dele disse um contemporâneo: «tomou algüas noticias de lingoa latina, que ao depois soube com perfeição por sua muyta, \& natural curiosidade, \& prompto engenho» (BENT M MaDeIRA Gastro, Breve resumo da vida de Brás Garcia Mascarenhas author deste poema, [Coimbra, 1699], transcrito por António de Vasconcelos, Brás Garcia Mascarenhas: estudo de investigação histórica, Coimbra, 1922, doc. CXII, p. 82 e p. 27). Era, com efeito, «um dos homens mais instruidos do seu tempo», no dizer do Prof. Carlos de Figueiredo [idem, p. 394); da profundidade da sua cultura clássica relativamente aos aspectos materiais e culturais da civilização romana, falam eloquentemente as estâncias que consagrou à arte militar (Canto II, oits. 6, 8-37 ; Canto IV, oits. 14-25, 28-32), suficientemente notáveis para terem sido plagiadas por ANDré Da Silva MASCARENHAS na sua «Destruiçam da Espanha» (Lv. III, oits. $3^{\wedge}-69,71-86$ ). Mas o seu conhecimento da Antiguidade não se esgotava na erudição livresca: conhecia nesta região diversos castros «pellas raízes desta serrania» (cf. Canto I, oit. 21), as «reliquias» de Conímbriga em Condeixa-a-Velha (cf. Canto V, oit. 18), as ruínas de Pombeiro da Beira (a que, por equívoco, chama Aufragia ao longo de todo o Canto IV), «centumcele ou cela», que deve ter sido o primeiro a julgá-la pretório de um acampamento (cf. Canto V, oits. 12, 44) e tantas outras que conhecia de visu. Sabemos, por exemplo, que logo após o regresso do homizio no Brasil visitou, ainda no ano de 1632, a chamada «Cava de Viriato», junto a Viseu (cf. António de Vasconcelos, Brás Garcia (...), Coimbra, 1922, nota 1, p. 147).

Conímbriga, 21 (1982), 101-126 
em grande parte sobre o poema, o estudo biográfico do autor $\left({ }^{16}\right)$, também não é fácil recusar o seu valor como fonte histórica; e, em relação a esta informação concreta, não será significativo que o poeta se credite dizendo: «Permanece um letreiro antigo d'esta [Julia Modesta]/Que muito claramente o testifica»? Tais são para nós, de momento, suficientes garantias para propor a seguinte reconstituição possível, se não provável:

\section{SPLENDIDISSIMAE CIVITATI IVLIA MODESTA FLAMINICA EX PATRIMONIO PORTAS REFECIT}

Que se traduzirá: «A esplendidíssima cidade (17), a flaminica Julia Modesta, à sua custa, reedificou (estas) portas». É este o mais simples dos textos que considerámos, unicamente retroversão literal dos versos portugueses - que, por suposto, seriam dele tradução - levando em linha de conta o que já tínhamos estabelecido para a primeira parte do texto e, no que respeita à segunda, os hábitos epigráficos da região $\left({ }^{18}\right)$. Outras se poderiam

(16) António de Vasconcelos, Brás Garcia Mascarenhas: estudo de investigação histórica, Coimbra, 1922. Sep. «Revista da Universidade de Coimbra», Coimbra, I (1) Mar. 1912, p. 14-76; I (2-3) Jun.-Set. 1912, p. 294-345; I (4) Dez. 1912, p. 758-795; II (1) Mar. 1913, p. 160-234; II (2-3) Jun.-Set. 1913, p. 328-423; VIII 1922, p. 5-236.

(17) «Devemos entender por splendidissima civitas o Génio da Civitas, embora não esteja declarado» (J. Leite de VAsconcelos, Religiões da Lusitânia (...), III. Lisboa, 1913, p. 299).

(18) Segundo os índices do CIL II, a expressão «EX PATRIMONIO SUO» ocorre na Península exclusivamente nas inscrições 396, 401 e 402, que são todas de Bobadela - Midões (cf. CIL II, supplementum, s. v. «Notabilia Varia», p. 1196). Como que a confirmar este facto apareceu, por volta de 1951, na Bobadela ,uma outra inscrição com o mesmo formulário: [ROM(ae) ET?] Aya (usto) ELAV[IVS?]/[ET S]VI PARENTEOS] / [EX PATRIMONIO / $/$ [POS]VERVNT (Museu Regional de Arqueologia de Arganil, n. ${ }^{\circ}$ de inv. 26, de 1952). Ver sobre esta inscrição Bob. Ep. 5, a páginas 55-62. Não será descabido referir aqui igualmente um monumento epigráfico recolhido na Idanha, e onde se pode ler a mesma expressão: é uma inscrição monumental de um templo de Vénus, porventura aquele de que subsiste o podium, e que deve ter sido posta pelo mesmo Modestino que, em Midões ou Bobadela, elevou o Templo à Vitória e prestou homenagem ao Génio do Município. Neste caso ler-se-ia: «[VENERJIS TEMPLVM / [C(aius) CANTI[VS MODES- 
encontrar mas esta, pela sua pròpria simplicidade, é a que imediatamente ocorre e melhor «responde» no conjunto, às condições prefixas: não colide em nada com o texto conhecido, dá sentido a toda a inscrição e adapta-se, excelentemente, ao espaço a preencher $\left({ }^{19}\right)$.

Mas o texto não é um fim em si: a nossa leitura suscita, desde já, observações e problemas que não pretendemos iludir. A primeira conclusão a extrair da nossa proposta de re(con)stituição, é a de que se trata de uma inscrição monumental: a «leitura» unívoca da inscrição não pode prescindir do seu contexto material e, na falta de mais do que a palavra portas, termo muito geral, a sua colocação devia deixar bem claro de que construções se tratava.

Supondo, por economia de hipótese, que a inscrição foi exumada não longe da «igreja velha», onde por muitos anos «se achou» e, sabendo-se que esta se situava dentro da área presumível do fórum romano, bem no centro da povoação actual, não custa admitir que se referisse às portas desse recinto. Por outro lado, julgamos possuir já evidências arqueológicas de que o fórum teria mais do que um acesso, o que confirmaria a restituição do texto, segundo Brás Garcia, com o uso do plural.

Uma dessas portas do fórum ainda se conserva razoavelmente (figura 5), não obstante a tenaz persistência com que tem sido agredida: o venerável «monumento nacional» serve hoje

TINYS /[...? EX.] PATRIMONIO. SVO). O facto de utilizar esta expressão «Ex patrimonio suo» dà, quanto a nós, grande consistência à hipótese de ter sido posta pelo mesmo personagem, hipótese esta avançada pela primeira vez pelo Prof. Dr. Jorge de Alarcão, há já uns anos (cf. Portugal Romano, Coimbra, 1973, p. 164). A expressão, que aparece abreviada na Bobadela confirmando largo uso local (desde a $1 .^{\mathrm{a}}$ metade do século i?), não só se concentra extraordinariamente aqui, como eclipsa até todas as fórmulas epigráficas equivalentes (de suo, de sua pecunia, propria pecunia, etc.). Simples moda local, ou formulário de urna oficina epigráfica ainda por caracterizar? Esperamos voltar, brevemente, a este assunto.

(19) Com efeito, obteríamos 35 letras e 3 espaços na primeira linha, «contra» 34 letras e 4 espaços na segunda, o que dá um total idêntico; só a abundância de ii na primeira poderia perturbar um paginador menos hábil! 
(Dezembro 1980) de suporte a uma conduta de águas, o que dá finalmente razão — pelo absurdo — aos que pretenderam considerá-lo vestígio de «um magnífico aqueduto» $\left({ }^{20}\right)$.

Outra argumentação sobre o carácter monumental e a situação que atribuímos à epígrafe talvez possa encontrar-se no próprio poema de Brás Garcia Mascarenhas: para ele, a cidade era fortificada, mas como não há qualquer vestígio, ou sequer verosimilhança de muralha, não custa admitir que foi o imponente muro de silharia almofadada do foro que lhe inspirou os vibrantes episódios do escalamento da cidade pelas hostes de Briseo e Vandermillo... Os 4,35 $\mathrm{m}$ do muro, com os seus mais de $90 \mathrm{~cm}$ de espessura, enquadram perfeitamente na ideia que sabemos que ele possuía das obras militares romanas: «As muralhas que de pedra inda agora achamos, / Eram (...) / Ao revés de epipharas que hoje usamos / Mais baixas, e mais bem descortinadas» (Canto II, oitava 18).

Poder-se-á ( ?) então deduzir que, na primeira metade do século XVII, restavam ainda bons pedaços do muro que, para norte e sul, haviam de prolongar o «arco» e constituir o recinto fechado de um fórum-bloco imperial? Ousamos pensar que uma reutilização que é ainda hoje evidente no arco - convertido em época medieval ou moderna numa larga porta com tranca - terá logrado preservar até essa época, como parede de pátio ou de edifício, uma boa parte do mtiro romano, com sua porta, e que Brás Garcia Mascarenhas o teria conhecido. Só com a demolição da estrutura moderna, mais leve, e que se estendia para poente, é que rapidamente se foi degradando o muro, a ponto de, em 1721, ser assim descrito: «no meio da V(ill)a peguado a praça esta hü Arco in solidum que parece Coiza ainda dos Guodos»(21). Neste conspecto parece-nos possível interpretar aqueles versos de

(20) José A. Marques Gomes e Joaquim de Vasconcelos, Exposição distrital de Aveiro em 1882: Relíquias da arte nacional, Aveiro, 1883, p. 35. Foi esta, também, durante algum tempo, a opinião de Vergilio Correia (Vergilio Correia, O domínio Romano em Portugal, in Damião Peres et aL História de Portugal (...) I, Barcelos, 1928, p. 269).

(21) Prior Miguel Alves Carrilho, Informações paroquiais (...), Bobadela, 1721, Maio 3, ms. A. U. C., foi. 3. 
Brás Garcia Mascarenhas «gastadas letras a memoria d'ella, conservam na ruinosa antiguidade», como referência provável à localização in situ do «letreiro», embebido ainda «na ruinosa antiguidade» em que aquele muro estaria então convertido...

Que o celebrado «Arco da Bobadela» e outros silhares, que aí identificámos, faziam parte do número das portas do fórum, provar-se-á, sem dúvida, a seu tempo! Que a inscrição à splendidissima civitas se lhes refira, será já matéria de mais difícil demonstração, por agora uma especulação que não desanimamos de ver um dia confirmada, já que irão prosseguir as escavações iniciadas pelo GAAC (Grupo de Arqueologia e Arte do Centro) e que certamente farão com elas prosseguir os estudos de erudição e de conjunto que a importância temática desta estação pode justificar.

É que estas não são meras questões académicas: o emprego, por exemplo, da forma refecit (reedificou) na inscrição pode sugerir que os fundamentos de portas, ou mesmo de um fórum mais antigo, jazem sob as ruínas dos que, presentemente, se reconhecem, enquanto, por outro lado, o estudo dos vestígios monumentais se pode reflectir no estudo da inscrição, sugerindo ajustamentos sobre a sua cronologia: primeira metade do século segundo?

Após o problema do carácter monumental da inscrição, há uma segunda questão em aberto que consideramos susceptivel de revisão face ao que a nossa hipótese de leitura traz de inovador: é o problema da identidade da splendidissima civitas. Para a Dr. ${ }^{a}$ Regina Anacleto, eia seria a urbs distante, a Roma Eterna, «associada, na sua perenidade, à pessoa augusta do Imperador» (22), hipótese sem dúvida sedutora mas que a nossa leitura não confirma: a civitas splendidissima fica de facto ali, na humilde Bobadela, contrafortes da Estrela, alto distrito de Coimbra.

Este epíteto (splendidissima), que ocorre em numerosíssimas inscrições de municípios e colónias romanas, nomeadamente na Península (CIL II 4114 e 4121, de Tarragona; ILER 2056, do circo de Mérida; etc.), parece mais relacionado com as civitates

(22) Bob. Ep., pp. 23-24. Cf. idem, p. 61. 
do qtie com a urbs: não conhecemos nenhum estudo dele, mas pode, talvez, fazer-se um paralelo cultural com o título splendidus (também splendidissimus) eques Romanus, que, a partir do séc. n, começa a aplicar-se a cavaleiros que, não tendo passado pelas milícias equestres, se distinguiram no exercício de funções do quadro municipal e regional. Deles diz Demougin: "Ces notables locaux ont accepté de veiller aux intérêts de plusieurs cités et surtout de patroner de nombreuses villes: plus de la moitié de nos splendidi ont été choisis comme patrons» (23).

Parece, pois, que aquele epíteto gravita, nas províncias, em torno da ideia de cidade e, neste caso, podemos pensar que a reconstrução das portas se insere no dispendio da summa honoraria a que o fiammato municipal obrigaria $\left({ }^{24}\right)$.

E então, como harmonizar o splendor desta cidade monumental, quase certamente uma fundação «de raiz» precoce e numa zona de importância política, com o aparente silêncio dos autores antigos?

Pensamos que, em boa medida, será este um falso problema, pois estando insuficientemente estudada toda a zona interior da Lusitânia e a identificação de muitas cidades estipendiárias e

(23) Ségolene Demougin, Splendidus eques Romanus, «Epigraphica», Faenza, XXXVII (1-2), 1975, p. 178. A instituição do patronato é conhecida também na Bobadela (CIL II 399).

(24) Não sabemos quando (nem sequer se) teria sido obrigatório o dispêndio de uma dada summa no exercício do fiammato «municipal» (que não existia só nos «municípios» propriamente ditos, mas nas colónias e cidades estipendiárias). Seja por obrigação ou por liberalidade, o facto é que temos, na Península, inúmeros exemplos deste procedimento «ob honorem pontificatus» (CIL II 1663): é a organização de jogos municipais ou de espectáculos de teatro (CIL II 1074), é a oferta e distribuição de trigo em anos de carência (CIL II 53 e 1574), a instituição de banquetes, a doação, unicamente, de uma soma em dinheiro (CIL II 1936 e 5523) ou dos juros delà, para a realização anual de um espectáculo de pugilismo e o abastecimento das termas em óleo ( CIL II 4514), etc. Muito vulgar deve ter sido a construção de diversas obras, como parece ser também o caso da nossa inscrição: é uma edícula (CIL II 1939), é um pórtico marmóreo (CIL II 1074), são estabelecimentos comerciais e celeiro ( CIL II 2129), são diversas estátuas e pedestais (CIL II 2103, 2126 e 5523), etc., etc.

Conimbriga, 21 (1982), 101-126 
municípios ainda por estabelecer com segurança, o problema não pode decidir-se (pela negativa) antes do fim daqueles estudos ou (pela positiva) sem o achado de um monumento que nos esclareça sobre o nome da cidade, «se o tempo escureceo como a chamavam».

Acrescente-se, contudo, que, a nosso ver, é provável que fosse município romano: está, infelizmente, por demonstrar que o termo civitas tivesse significado jurídico. Mas, a poucos quilómetros, no Coito de Midões (concelho de Tábua) há urna bela inscrição monumental (CIL II 401) que Gaio Câncio Modestino dedicou ao Genius Municipii (25). Alguns autores supõem-na proveniente da Bobadela, mas nâo há disso evidências.

\section{INSCRIÇÃO N. ${ }^{\circ} 3($ CIL II $396=$ ILER $463=$ Bob. Ep. 6)}

Sobre o perdido monumento à Piedade poucas certezas parece haver: «Do monumento em si, nada se sabe ao certo. Conhece-se apenas a legenda, que se supõe bem copiada. Hübner deu-lhe o seu aval»(26).

Mesmo o que se cria seguro, verifica-se hoje náo corresponder à realidade: diz-se, por exemplo, na «Bobadela Epigráfica», que teria sido encontrada e deslocada para Coja, para o palácio do Bispo de Coimbra, «com certeza» entre 1721 e 1758 (27) : isto porque, náo sendo referida pela «Informação Paroquial», datada de 6 de Maio de 1721, aparece no $1 .^{\circ}$ tomo da obra de Frei Tomás da Encarnação, naquela data. Tal não é, porém, tão evidente : lendo a obra de Encarnação - por sinal editada em 1759, como se pode ver no rosto (figura 6A) - verifica-se facilmente

(25) A leitura corrente (GENIO MUNICIPI... etc.) tem levado a pensar que se tratava de um génio de nome Municeps, mas uma análise mais cuidadosa da lápide, demonstra, no entanto, que «municipi» termina em «i alto», que pode significar nexo de dois $i i$, como acontece na palavra «MUNICIPI» das inscrições CIL II 1362 e 2135, por exemplo (cfr. Jesus Victor Rodriguez Adrados, Usus de la I longa en CIL II, «Emerita», Madrid, XXXIX (1) 1971, p. 162-163). Seria, então, um genitivo: Génio do Município...

(26) Bob. Ep. p. 64.

(27j Cf. Bob. Ep. p. 63-64. 
que o monumento foi feito transportar de Bobadela para Côja, por D. Jorge de Almeida, bispo de Coimbra entre 1483 e 1543 (28): «In Beirensi Provincia apud oppidum de Coja in aedibus Episcopi Colimbriensis inscriptus est lapis, quem D. Georgius de Almeida Colimbriensis Episcopus ex antiquissimo aedificio oppidi de Bobadela asportari fecit» $\left({ }^{29}\right)$.

A comprovar a antiguidade do seu achado pode citar-se o facto de já ter sido, possivelmente, referida pelo poeta Brás Garcia e de, em 1758, o palácio se encontrar desocupado desde há muito, inclusivamente com a capela arruinada $\left({ }^{30}\right)$. Portanto, o edifício não só não foi construído no século xvm ( $\left.{ }^{31}\right)$, como estava já tão velho que o povo dizia «ter sido doado em palácio aos Bispos de Coimbra, por uma grande Matrona Romana; e se apoia à [sic] tradição na referida inscripção» (32), pormenor assaz curioso do folclore relativo a vestígios arqueológicos...

Ainda com respeito á história da inscrição, se andavam erradas as notícias acerca do seu «achamento», igualmente nos

(28) Dada a controvérsia acerca da investidura deste distinto prelado, tomamos estes milésimos da obra mais tardia do seu principal biógrafo (António de Vasconcelos, Lista Cronológica dos Bispos de Coimbra, Coimbra, 1924, p. 19).

(29) Frei Tomás da encarnação, Historia Ecclesiae Lusitanae per singula saecula ab Evangelio promulgato, 7, Coimbra, 1759, p. 58.

$\left.{ }^{30}\right)$ «i3 (...) fora da mesma vila, mais ha huma capela junta dos passos em que antigamente assistiam parte do anno os Bispos de Coimbra, arruinada de sorte que só se conservam as paredes, o altar, e a memoria de ter sido matriz da freguezia» (Vig. ${ }^{\circ}$ Bento Marques Quaresma, Informação Paroquial de 1758, in: Diccionario Geografico de Portugal, manuscrito da T. T., transcrito por JoÃo Nuno Montenegro de Pina Aragão, Aspectos Saciais e Económicos de Coja no século XVIII. Tese de licenciatura apresentada à Faculdade de Letras da Universidade de Coimbra (polie.), Coimbra, 1968, p. XII).

$\left.{ }^{31}\right)$ O palácio original deve ser muito anterior à atribuição do título de «Senhores de Coja» aos bispos de Coimbra (25 de Setembro de 1472): Um documento de Julho de 1088 já refere o palácio do bispo de Coimbra, D. Bernardo. (Cf. Arquivo da Universidade de Coimbra - Livro Preto da Sé de Coimbra, I, Coimbra, 1972, doc. CLXVII, p. 262-263).

(32) Balthasar da Silva LisBoa, Viagens feitas à ordem do Bispo Conde no paiz de Coja em 1782. Códice 2549 da Biblioteca Geral da Universidade de Coimbra, B. G. U., foi. 8. 
parecem controversas as do seu desaparecimento: o palacio foi demolido no século passado e dele só resta um troço de muro arruinado e o topònimo «o paço»; da inscrição dão-se vagamente conta os autores do «Inventário» da Academia: «parece que se encontra empregada como material de construção duma casa» ( ). Dir-se-ia, com efeito, que toda a gente em Coja está convencida disso, e a própria Dr. ${ }^{\text {a }}$ Regina Anacleto nos deu conta de prolongados esforços para a encontrar aí. Pessoalmente, estamos convencidos de que a inscrição foi despedaçada e dispersa, não sendo de afastar, contudo, a ideia de que algum fragmento

_quiçá importante — tenha ficado em Coja, na alvenaria de uma

parede. Adiante se verá donde nos vem esta certeza.

Outra questão problemática é a tipologia do monumento: para muitos autores seria uma ara $\left({ }^{34}\right)$, o que a nosso ver só pode ser conjectura; nisto, como em tudo o que diz respeito a monumentos perdidos, faltará sempre a certeza lapidar enquanto não encontrarmos... a lápide! Porque tudo indica, com efeito, que de uma lápide se tratava: não só o diz claramente Frei Tomás da Encarnação (ver facsimile na figura 6B), como o facto conhecido de estar na porta do palácio se acomoda mal à forma de ara; um autor que esteve em Coja em 1782 é mais explícito ainda, ao dizer que «foi imposta na verga da porta do dito palácio» (35), e, noutro manuscrito, esclarece que é «na entrada do páteo»(36). Podemos pois imaginar que seria um texto cuja maior dimensão se dispunha no sentido da largura, como na inscrição que atrás vimes.

Todo o erro dos que a consideraram como ara decorre, salvo melhor opinião, da forma como Hübner dispôs o texto no

(33) A. Nogueira gonçalves e Vergilio Correia, Inventário Artístico de $\quad$ Portugal, IV. Distrito de $C$ o $i m b r a$, Lisboa, 1952, p. 13.

${ }^{(34)}$ A. Nogueira gonçalves e Vergílio Correia, Inventário Artístico de Portugal, IV: Distrito de Coimbra, Lisboa, 1952, p. 165, copiado por Câmara Municipal de Oliveira do hospital (compilador), Concelho de Oliveira do Hospital: informação turística (polie.) Oliveira do Hospital, 1979, p. 41. a inurn. e idem (impresso) p. 34; Jorge de Alarcão, Portugal Romano, Lisboa, 1973, p. 165.

(35) Balthasar Da Silva Lisboa, Viagens feitas à ordem do Bispo Conde no paiz de Coja em1782. Cód. 2549 da B. G. U. C., fi. 8v. 
título do corpus: tomando por base o de Encarnação, limitou-se a adaptá-lo: «arredondou-o» para seis linhas, «restituiu-o» à grafia original e «alindou» tudo com puncti... Ora, um olhar mais atento à mesma obra não deixa dúvidas de que as paginações são aí um mero «acidente» tipográfico. Nada têm a ver com a ordinatio de cada texto epigráfico, já que todas as inscrições se distribuem uniformemente numa mancha de $94 \mathrm{~mm}$ (figura 6B).

Ora se a paginação de Encarnação, Hübner e seus seguidores só por mero acaso pode corresponder à da epígrafe original, seria boa ocasião de analisar um texto de Carlos da Anunciação, a que se não tem dado grande importância: só Jordão e Regina Anacleto o transcrevem, sem ousar fazer a opção entre os dois textos: Levy Maria Jordão que sob o número $620 \quad\left({ }^{37}\right)$ apresenta a versão de frei Tomás da Encarnação (sem interesse como vimos),

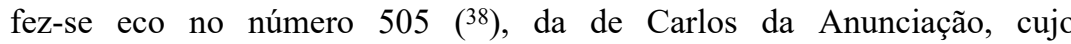
facsimile vai na figura $7\left({ }^{39}\right)$.

Há em nosso entender algumas razões para admitir que seria esta, pelo menos nos seus traços gerais, a paginação da epígrafe perdida:

- A primeira, e não será este um grande argumento, é que não temos nas fontes disponíveis, outra mais verosímil.

(36) Balthasar da Silva Lisboa, Viagem que de Coimbra à Villa de Coja fez no anno de 1782 o Doutor Balthesar da Silva Lisboa offerecida ao Exmo. e Brno. Sur. D. Francisco de Lemos de Faria Coutinho, do concelho de S. Mage. Bispo de Coimbra, Conde de Arganil e Senhor Donatário da mesma Villa de Coja (...), cópia manuscrita, in miscelânia sem título próprio (fis. 21-41) da biblioteca da Academia das Ciências de Lisboa (série vermelha, . $^{\circ}$ 697), $§ 12$ foi. $25 \mathrm{v}$.

(3') LeVy Maria Jordão, Portugalliae Inscriptiones Romanas, I. Lisboa, 1859, p. 264.

(38) LeVy Maria Jordão, Portugalliae Inscriptiones Romanas, I. Lisboa, 1859, p. 221.

(39) Carlos da AnunciaÇão, De locis quibus oblata quondam; quibus modo offerri congruat Liturgiam, in: Bernardo da AnUnciação, Colectio Institutionem Academiae Liturgicae Pontificiae exhibens, atque lucubrationes anni 1758. Annus II, Coimbra, 1761, p. 438. 
- A segunda é a função com que, já referimos, foi reaproveitada em Coja.

- A terceira é que existe um fragmento «inédito» que dificilmente se poderá sustentar que náo pertença a este texto.

Será, talvez, excessivo dizê-lo «inédito», mas como náo é estudado na bibliografia bobadelense, nem táo pouco em outras publicações, tão completamente como aqui, o termo representa razoavelmente a sua posiçáo no panorama dos nossos conhecimentos, muito embora possua já uma pequena bibliografia $\left({ }^{40}\right)$.

O fragmento, proveniente da Bobadela, onde teria sido achado «perto do arco» $\left({ }^{41}\right)$ em data que ignoramos, é propriedade do Museu Nacional de Machado de Castro, em Coimbra, com o número de inventário 3895 (antigo).

Não sabemos quando nele deu entrada: podia já aí se encontrar em 1916, pois o pequeno roteiro que entáo se editou - e que o náo refere — esclarece que «dentre os diversos monumentos (...) legendas mortuárias ou comemorativas, poucas seráo mencionadas $\wedge^{\wedge 2}$ ). Estaria este entre os não referidos?

De certeza, sabemos que em 1941 se achava exposto na sala 3 da «Galeria Romana», com o n. ${ }^{\circ} 26\left({ }^{41}\right)$, que ainda vem

(40) Museu Nacional de Machado de Castro, Seç̧ões de Arte $e$ Arqueologia, II. Catálogo-Guia, Coimbra, 1941, n. ${ }^{\circ} 26$, p. 11; Bı́віотеса Nacional de Lisboa, Guia de Portugal III: Beira Litoral, Beira Baixa e Beira Alta. Lisboa, 1944, p. 864; A. Nogueira Gonçalves e Vergilio Correia, Inventário Artístico de Portugal IV: distrito de Coimbra, Lisboa, 1952, p. 165; M. DE LuRdes Rodrigues, Inscrições Romanas do Museu Machado de Castro, «Humanitas», Coimbra, XI, 1959-1960 (tem separata); ANA CÂndida Silva, Subsídios para o Estudo da Epigrafia romana em Portugal. Dissertação de Licenciatura em História apresentada à Faculdade de Letras (...) (polie.), Coimbra, 1968, n..$^{\circ}$ 17, p. 465-466; (ref. indir.), Jorge de Alarcào, Portugal Romano, Lisboa, 1973, p. 99; C. M. O. H., Concelho de Oliveira do Hospital: Informação turística (polie.), Oliveira do Hospital, 1979, p. 41. a inum.

(41) M. N. M. C., Secções de Arte e Arqueologia, II. Catálogo-Guia, Coimbra, 1941, p. 11.

$(42)$ A. Augusto N. Gonçalves, Museu Machado de Castro. Aotas, Coimbra, 1916, p. 12. 
incluído, em 1960, no catálogo de M. de Lurdes Rodrigues ( $\left.{ }^{43}\right)$ e que, em 1970, Fernando Dias Coelho só não o achou nas suas «deambulações» por aquele museu $\left({ }^{44}\right)$ porque recolheu às reservas da instituição, onde o encontrámos em Março de 1981.

Como se pode ver pela foto da figura 8, a letra é capital monumental quadrada, em bisel bem marcado, elegante, do séc. $n$. Tem de altura (máxima) $37,5 \mathrm{~cm}$, e de largura (máxima) $60 \mathrm{~cm}$. É de granito, tem cerca de $20 \mathrm{~cm}$ de espessura $\left({ }^{43}\right)$ e a superfície do campo epigráfico pouco regular.

Altura das letras:

1. $1: 8 ; 1.2: 8,5(8,2$ para os $i$ e o s $) ; 1.3: 8$.

Espaços interlineares:

$1: 3,4+? ; 2: 4 / 4,5 ; 3: 3,7 / 4,3 ; 4:$ ?

Lê-se:

$[\ldots] 0$ IN HON[OREM] vel (orem) $[\ldots ?] /[\ldots]$ VI FLAMINIS $[\ldots ?] /[\ldots]$ ÓRVM PAR vel RAP $[\ldots]$

e traduz-se:

$$
\text { «... em honra de ... flàmine...» }
$$

Verifica-se facilmente que este monumento se adapta bem ao que seria a «retroversão» para caracteres epigráficos do título de Anunciação (Fig. 9). A coincidência é tão perfeita que pode até sustentar-se, com base nela, que a palavra provinciae, no final da segunda linha, estaria aí indevidamente abreviada.

Aceitamos que se considere abusiva esta conclusão, porque nenhuma das leituras feitas supostamente do original íntegro a

(43) M. de Lurdes Rodrigues, Inscrições Romanas do Museu Machado de Castro, «Humanitas», Coimbra, XI-XII, 1959-60, p. 16.

${ }^{44}$ Fernando Manuel de Vasconcelos Dias Coelho, Bohadela, Encruzilhada de Dúvidas: dissertação de licenciatura em Ciências Históricas, apresentada à Faculdade de Letras (...), (polie.), Coimbra, 1970, p. 87. 
autoriza. Não incluímos na reconstituição provisória a invocação Pietati Sacrum apresentada em itálico pela nossa fonte principal de informação e omitida - com que fundamento ? - por Jordão. Fazemo-lo unicamente devido à falta de informação já que estamos convencidos de que existia no original: o facto de poder estar destacada do resto da mancha do texto, de aparecer em módulo diferente ou de estar muito mutilada podem ser, isoladamente ou no conjunto, explicações aceitáveis para a anomalia de transcrição detectada. Não tendo materiais para ensaiar a sua possível reconstituição preferimos deixar o croquis assim mesmo...

Funerária, votiva ou honorífica - qualquer destas classificações tem os seus defensores — trata-se, sem dúvida, de um magnífico e imponente monumento. Segundo a nossa reconstituição provisória, não poderia ter menos de 3,20 de largura! Talvez fosse moldurada, uma vez que temos a opinião de um erudito viajante que, podendo admirá-la em 1782, achou que «bem podia ser achada em algum túmulo sepulchral da família dos Júlios que habirão em Portugal» $\left({ }^{45}\right)$, com o que talvez não tivesse andado longe da verdade: a hipótese de ser funerária, ou «semi-funerária» na terminologia conciliadora de J. Leite de Vasconcelos (46) longe de lhe «diminuir (...) o alcance cultural» $\left({ }^{47}\right)$ é, a nosso ver, a mais verosímil e enriquecedora.

Em primeiro lugar, seria mais um exemplo a atestar, na Hispânia, a tendência já detectada por Cagnat, para a colocação dos monumentos funerários sob a invocação de divindades superiores do panteão clássico ${ }^{48}$ ). Depois é, de tal carácter-《acentuado» pela fórmula in honorem $\left.{ }^{*}\right)$ - se poder concluir, com

(40̃) Balthasar da Silva Lisboa, Viagens feitas à Ordem do Bispo Conde no paiz de Coja em 1782, Cód. 2549 da B. G. L. C., foi. 8v.

(46) José Leite de Vasconcelos, Beligiões da Lusitânia (...) III, Lisboa, 1913, p. 302.

(47) Bob. Ep., nota 11, p. 68.

(48) Cf. RENé Cagnat, Cours d'épigraphie latine, 4.ième éd. revue et augmentée, Paris, 1914, p. 282.

(49) Cf. Robert etienne, Le culte Impérial dans la Péninsule Ibérique d'Auguste à Dioclétien, Paris, 1958, p. 348-349. 
grande probabilidade, que $\mathrm{o}$ importante flàmine da Provincia ali teria sido sepultado e, portanto, dali seria também natural. Finalmente, é a possibilidade de, dadas as dimensões e tipologia suposta da peça, ser possível encarar a existência de um grande monumento funerário, um mausoléu, de que se conhecem tão escassos exemplos no território que é hoje Portugal. Não nos esqueçamos de que a inscrição foi levada por D. Jorge de Almeida de um «antiquíssimo edifício». Que mais poderia ele ser ?

Para o esclarecimento possível de todas estas questões, concorrerão talvez certas fontes marginais e manuscritos que Hübner não conhecia ou, conhecendo, não utilizou e que ainda trazemos em estudo; das eventuais alterações que a sua análise possa introduzir nestas conclusões provisórias, daremos conta no nosso «Inventário».

E parece-nos que o que ficou dito, é quanto basta à ideia que pretendíamos dar e que é a seguinte: apesar de aparentemente conhecidos, tanto o extravio da inscrição à Pietas (ern Coja, reutilizada) como o achado do fragmento publicado (na Bobadela, junto ao Arco), a coincidencia entre as duas peças é, no mínimo, perturbadora. Tudo indica que estamos perante um único monumento cuja historia, plena de equívocos, apenas começamos a vislumbrar e à luz do qual boa parte do dossier epigráfico da Bobadela terá de ser revisto: reavaliação global das fontes, cronologia das duas mais importantes inscrições, hábitos epigráficos e prováveis oficinas, vivência cultural que supõem, etc.

Para terminar, não encontramos melhor que aquela exortação do poeta que tão bem se aplica a estas antiguidades que, pela sua mão, tentámos «desenterrar»:

«Mas investigue-as sempre o curioso,

Que Portugal, por falta dos passados, He todo hum cemitério respevtoso».

Canto V, oitava 40

Conimbriga, 21 8(192), 101-126 


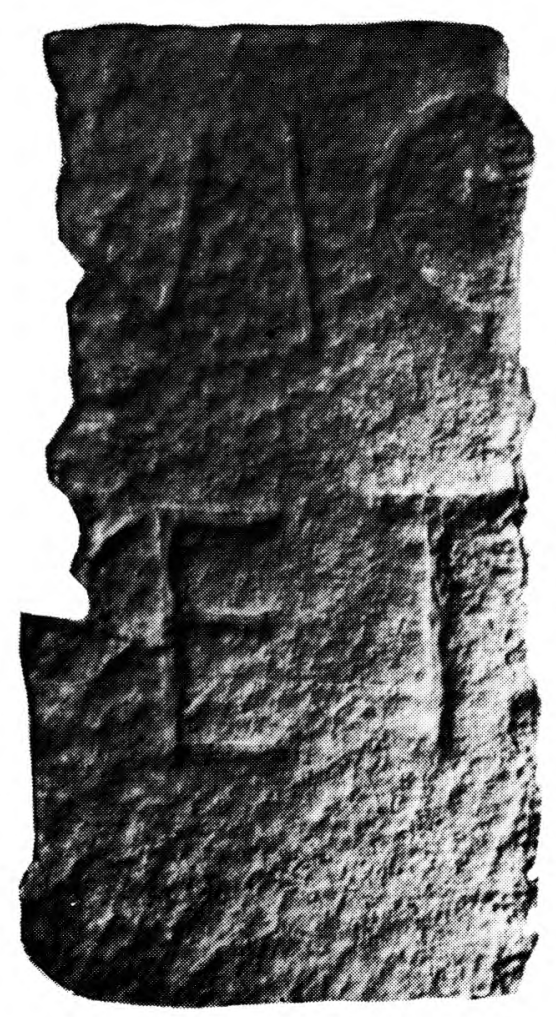

FIG. 1

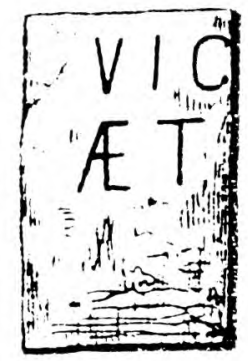

segundo Martins Sarmento tamanho natural

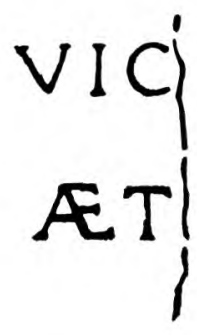

segundo Emilio Hübner-esc. $3: 1$

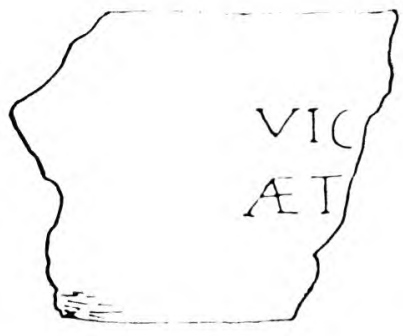

segundo Regina Anacleto esc.1:?

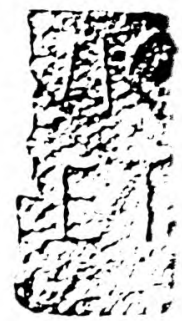

original

FIG. 2 

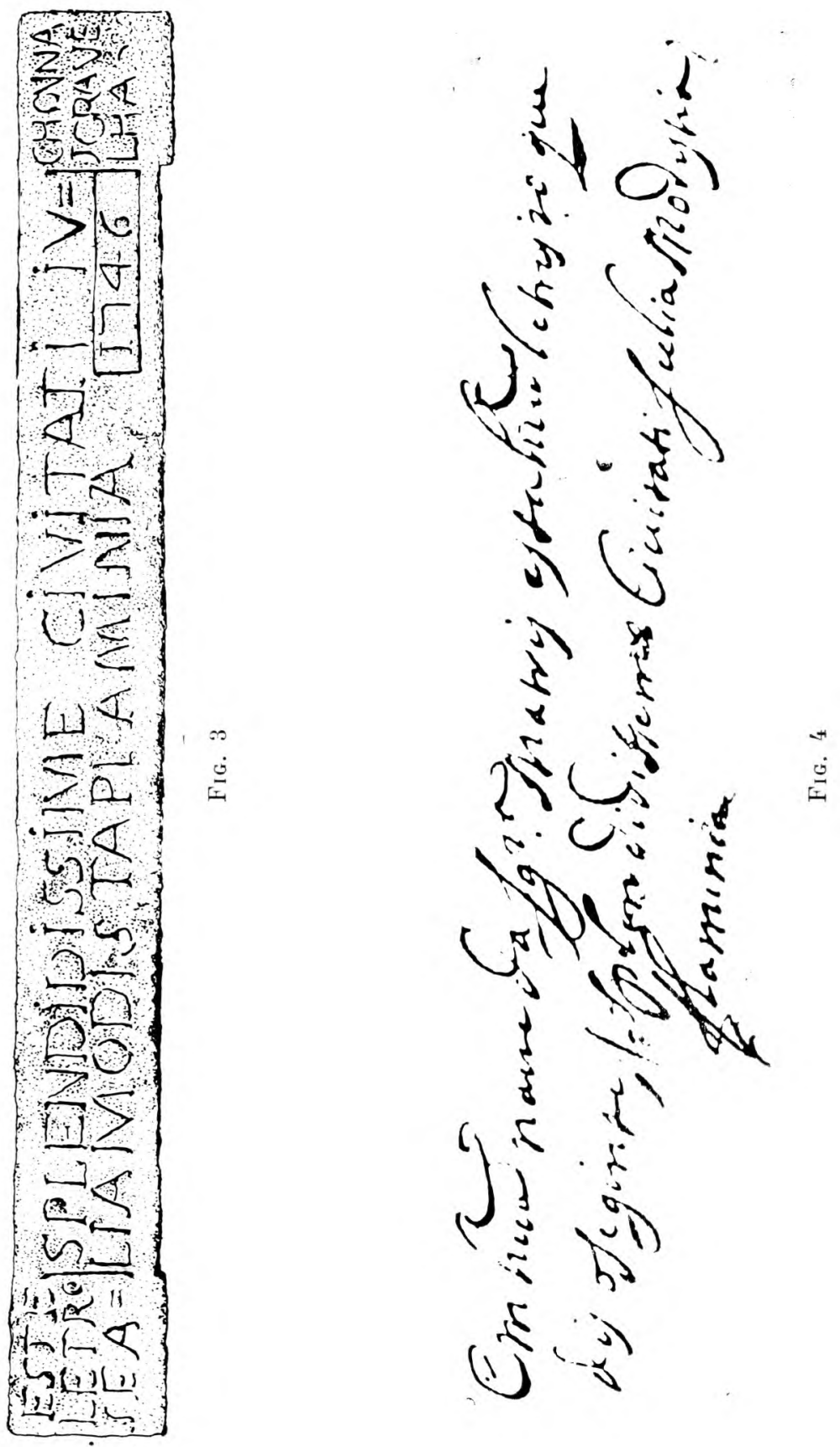


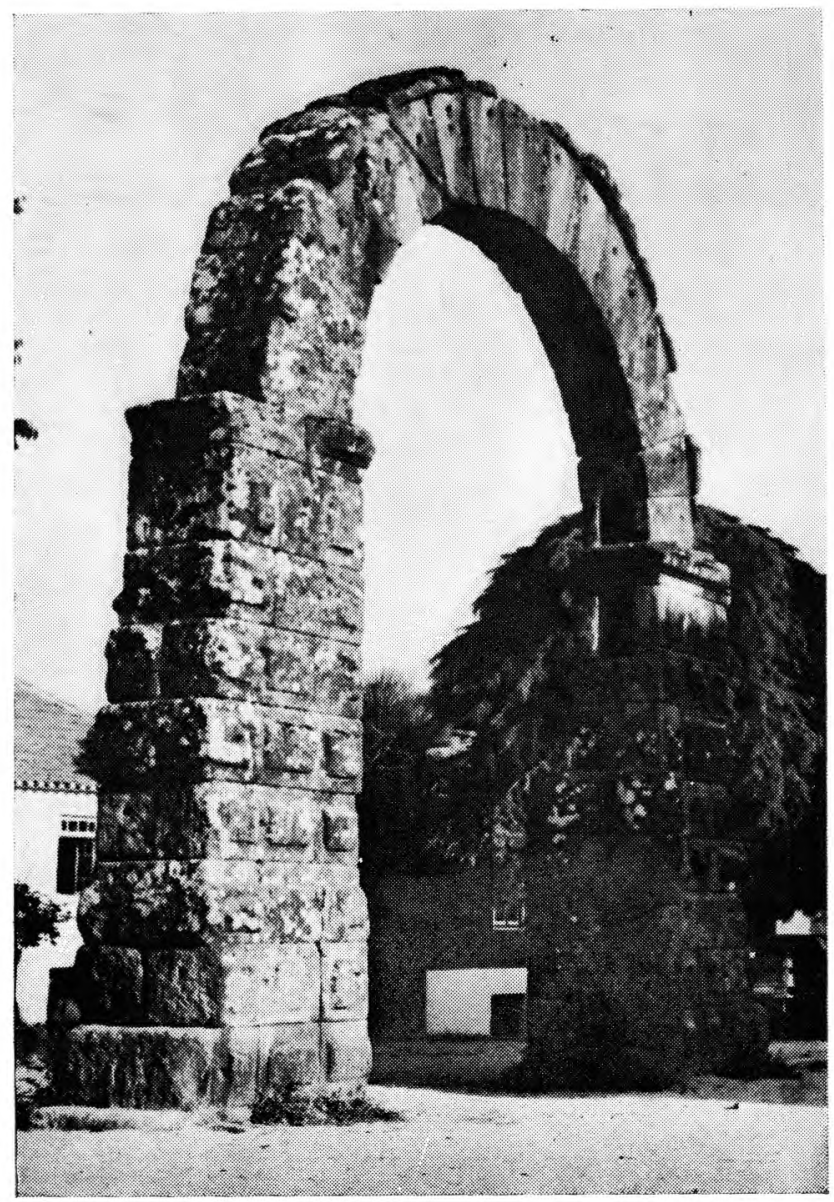

FIG. 5 


\section{HISTORIA \\ ECCLESI A \\ L U S I T $\triangle$ N E

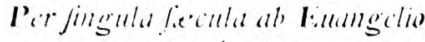 promulgato: \\ AUC:IORE}

1). THODA AB INCARNATYONE

Comonion Regulari laterancenfi congreqatomis Re-

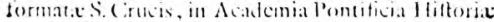

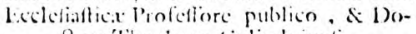
are'theologo colimbricuti.

TOMLSI

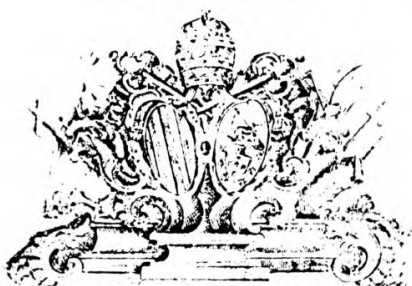

COLIMBRIA: MDCCLYX.

Ex Praco Acad mix Pontificia. Supos iortum pormiffu.

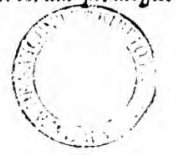

Fig. 6-A 
in templo, cujus ligna in petra infisipta pottmodun appataic

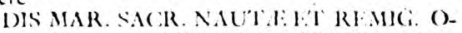

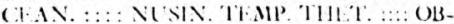

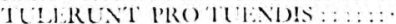

$$
\text { 1.. V.1). 1). }
$$

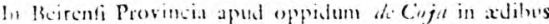

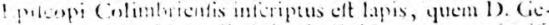

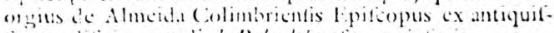

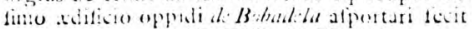

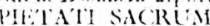

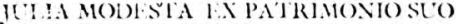

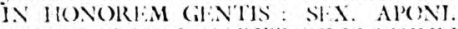

SC:ALYI I.I ACCI MARI'I SUI IIALIINIS

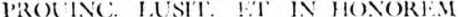

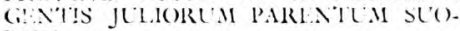
12:M

In Povincia Interamni apud Rracaram Auguftam lis po-

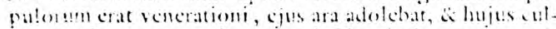
sus maximus crat ; de yuo ctt ifte titulus unde pori

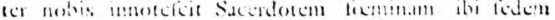
collosetits.

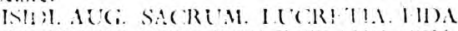

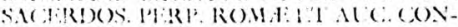
YUNLLS. BRAC:RA ALC;

$$
\text { V. 1). }
$$

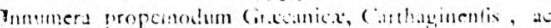

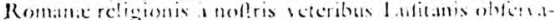

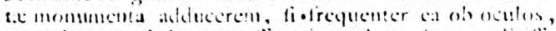

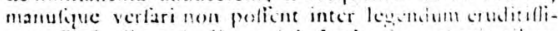

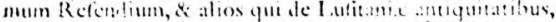

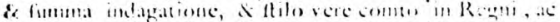

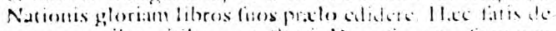

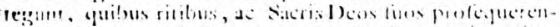

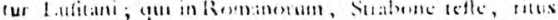

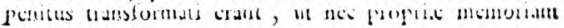

FIG. 6-B 
Apud Cojenfe Oppidum in oftio atrii ante Palatium E. pifcopi Collimbrienfis quidam inventrur lapis illue ex antiquiftimo edificio oppidi de Bobadella a D. Ceorgio de Almeida ejufdem Dioecefis Epifcopi afportatus, prout legitur in verulto codice hujus Regalis Monaftern S.Crucis Chartophilacio aftervato. In hoe autem lapide per tres valde oblongas lineas fequens repentur mferincio.

\section{Piatals Saitum}

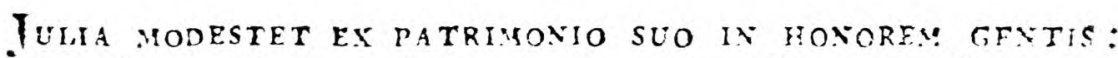
Six Aponi SCaevi flaci mariti sui flaminis proinc. Lusit. et is hoNorem gantis Juliorum Parentem slorum.

Julia Modefta ex patrimono fuo in honorem gentis Sexti A ponii Sexw mariti fui Flamms Provincla Lufitana, $\mathcal{E}$ in honorem gentis Juliorum Parcntum fuorum.

FIG. 7 

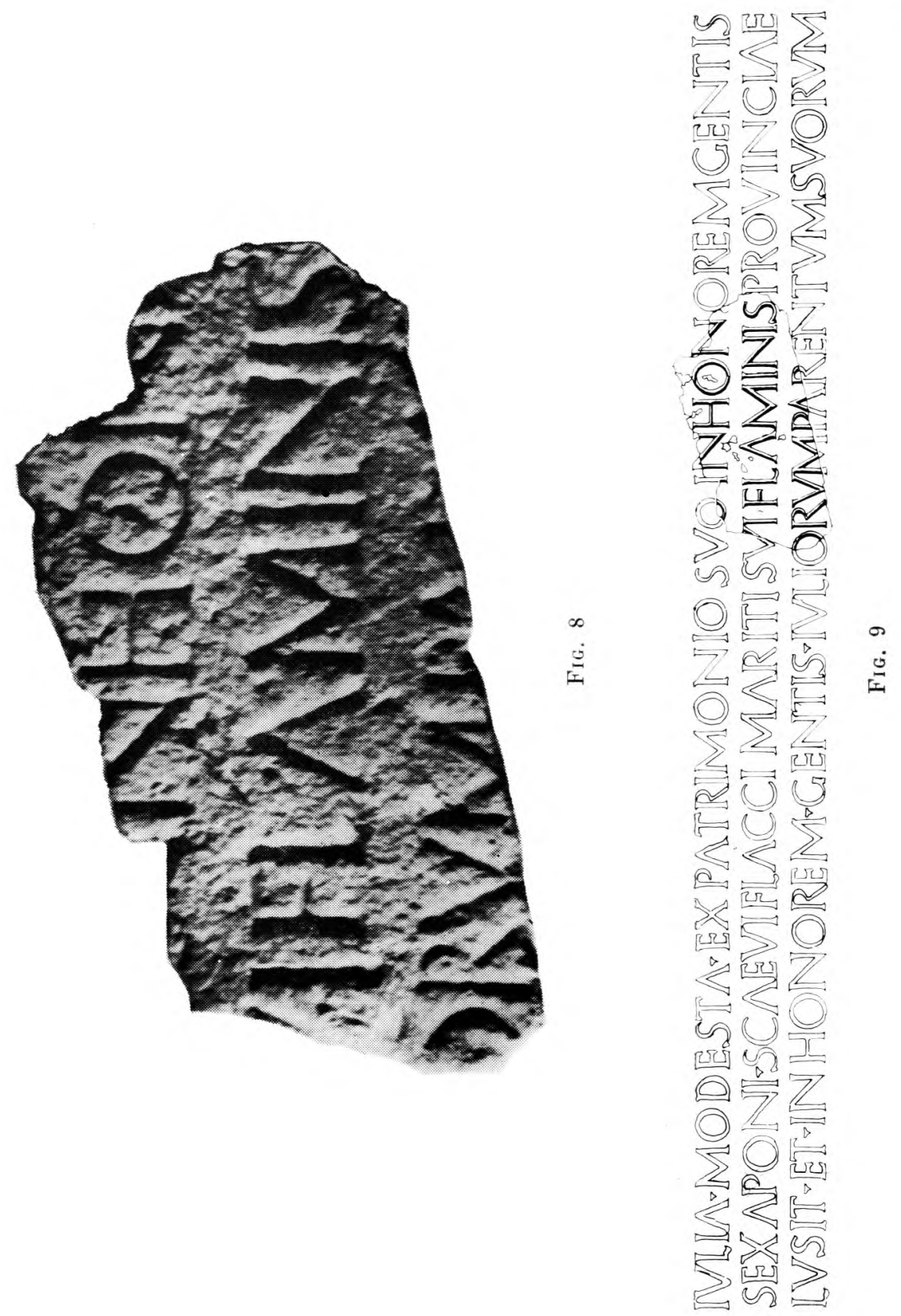